\title{
Canopy composition as a measure to identify patterns of nutrient input in a mixed European beech and Norway spruce forest in central Europe
}

\author{
S. Mohammad Hojjati · Anna Hagen-Thorn • \\ Norbert P. Lamersdorf
}

Received: 10 September 2007/Revised: 10 August 2008/Accepted: 11 September 2008/Published online: 1 October 2008

(C) The Author(s) 2008. This article is published with open access at Springerlink.com

\begin{abstract}
The influence of canopy composition on litterfall and throughfall was investigated in a mixed spruce beech forest in central Germany. We hypothesised that different parts of the mixed canopy created distinct patterns of element inputs via litterfall and throughfall. The investigation was carried out in two plots, representing the most contrasting cases of mixed forests: a stand greatly dominated by spruce (SDP) and a stand greatly dominated by beech (BDP). The canopies of the two plots were classified in four categories: pure beech, pure spruce, mixed canopy and gap. Amounts of throughfall water were lower and major element fluxes were higher under spruce than under beech in both plots, indicating that the nutrient inputs under the canopies of individual trees are driven by speciesspecific properties of the canopies and are quite independent of the degree of admixture. With the exception of $\mathrm{K}^{+}$, mixed canopies showed intermediate element inputs via throughfall, compared with pure canopy classes. The $\mathrm{K}^{+}$ input was significantly greater under mixed canopies, and these differences were more pronounced in the SDP than in the BDP. Results suggest that individual spruce trees in the BDP induce greater spatial heterogeneity of throughfall input than individual beech trees in the SDP. Nutrient inputs via foliar litterfall were similar among the different
\end{abstract}

Communicated by A. Merino.

S. M. Hojjati $(\bowtie)$ · A. Hagen-Thorn · N. P. Lamersdorf Buesgen Institute, Soil Science of Temperate and Boreal Ecosystems, Georg-August University of Goettingen, Buesgenweg 2, 37077 Göttingen, Germany

e-mail: shojjat@gwdg.de

S. M. Hojjati

Department of Forestry, Natural Resources Faculty,

Mazandaran University, Sari, Iran canopy classes, but the Mg input was lower under spruce canopy. This effect was balanced by higher $\mathrm{Mg}$ input via spruce throughfall. In our study, throughfall was the main source of heterogeneity in nutrient inputs, while foliar litterfall had a homogenising effect.

Keywords Canopy classes - Throughfall - Litterfall · Canopy leaching $\cdot$ Water fluxes · Gaps

\section{Introduction}

In the past centuries, the natural European beech (Fagus sylvatica $L$.) dominated forests in central Europe have to a large extent been replaced by Norway spruce (Picea abies L. Krast.) plantations (Rothe et al. 2002a). These monocultures tend, however, to be more sensitive to natural and anthropogenic forms of stress such as storm events, insect attacks, droughts and other impacts of climate change. Mixed forest types are currently recommended by foresters in order to improve the stability and biodiversity of forest ecosystems (Larsen 1995; Olsthoorn et al. 1999; Hooper et al. 2005). Admixture of beech trees to Norway spruce stands may have a positive impact on the biogeochemistry of forest ecosystems especially in areas with increased loads of atmospheric pollutants and on soils that are low in base cations (Sverdrup and Stjernquist 2002).

Litterfall and throughfall are the major pathways for elements to return from forest canopies to soil. The contribution of each of the two pathways is mainly dependent on the nature of elements, foliage properties and rain water acidity (Rothe et al. 2002a; Stachurski and Zimka 2002; Langusch et al. 2003; Hagen-Thorn et al. 2006; Lovett et al. 1996). In order to find the best solution to maintain the soil nutrient status in a given environmental condition it 
is of crucial importance to know how the chemistry and amounts of throughfall and litterfall depend on changes in canopy composition.

The differences in chemical composition of litterfall between beech and spruce have been previously demonstrated by several authors (Rothe 1997; Augusto et al. 2002; Borken et al. 2002). Admixture of European beech and Norway spruce can not only change the quality, quantity and spatial distribution of litterfall (Rothe and Binkley 2001), sometimes it can even improve the nutrient status of spruce trees (Thelin et al. 2002).

The spatial pattern of litterfall is related to wind velocity and the weight of litter materials (Lebert et al. 2001). In a mixed beech and spruce stand, the higher mobility of beech leaves in space can result in different distribution of litterfall (Rothe and Binkley 2001).

Tree species with different foliage properties exhibit different patterns of throughfall water and ion fluxes (Beier et al. 1993; Hansen 1995; Whelan and Anderson 1996; Raat et al. 2002; Staelens et al. 2006). Furthermore, as dry deposition is a function of foliage properties (Lovett 1994), it may cause species-related input fluxes (Rothe et al. 2002b).

Compared to beech, spruce can intercept more precipitation as well as capturing more air particles and gasses because of denser foliage, higher leaf area index (LAI) and higher foliage longevity (Rothe 1997). Hence, throughfall samples under spruce are, in general, richer in elements compared to throughfall samples under beech in the same site condition (Růžička 1994; Meesenburg et al. 1995; Rothe et al. 2002a; Oulehle and Hruška 2005). The pH of the throughfall under spruce is normally lower than under beech because spruce captures higher hydrogen loads from the atmosphere and has a lower capacity for proton buffering compared with broad-leaved species (Stachurski and Zimka 2002). The amount and chemistry of throughfall in a mixed stand is not only influenced by the foliage surface properties of individual trees but is also affected by the pattern of crown projection or the formation of gap and canopy overlapping (Wilpert and Mies 1995; Zirlewagen and von Wilpert 2001).

Tree composition affects ecological properties on a small spatial scale (Zinke 1962), and in a mixed forest the heterogeneity in canopy composition may create different representative structural units (Wilpert and Mies 1995; Wilpert et al. 2000) with different ecological characteristics, fluxes of water, nutrients and energy. The research on nutrient cycling in mixed forest could thus greatly benefit from studies on a small spatial scale where interaction between different trees takes place (Rothe and Binkley 2001).

The complexity of the canopy structure of a mixed forest stand makes it difficult, however, to apply the methods commonly used to describe small-scale spatial patterns of water and nutrient inputs in monoculture stands. Therefore, in contrast to other investigations, where the spatial patterns were described in relation to the distances from neighbouring trees or foliar density (Beier et al. 1993; Staelens et al. 2006), we used different types of canopy compositions (canopy classes) to identify the variability of input fluxes. Four canopy categories were identified: pure spruce, mixed spruce and beech, pure beech and gap. The main objectives of our study were, therefore, to find out whether the nutrient return via litterfall and throughfall will differ under these canopy categories and to quantify the element fluxes. The four selected canopy categories can be distinguished in any type of mixed beech-spruce stand. However, the relative differences between those canopy categories may differ depending on the proportional contribution of each of the tree species to the stand composition. Thus, we have decided to investigate two widely contrasting cases: a stand greatly dominated by beech and a stand greatly dominated by spruce.

The following hypothesis were, therefore, put forward in our study: (1) the four different canopy classes will show different nutrient inputs due to differences in amounts and chemistry of litterfall and throughfall and (2) these differences will be similar in two widely contrasting types of mixed beech and spruce stands growing at the same site.

\section{Materials and methods}

\section{Site description}

The study was conducted between May 2005 and July 2006 in Solling Forest, in central Germany. The site is located approximately $50 \mathrm{~km}$ north-west of Göttingen in Lower Saxony $\left(51^{\circ} 47^{\prime} \mathrm{N}\right.$ and $\left.9^{\circ} 37^{\prime} \mathrm{E}\right)$ at an altitude of $250-300 \mathrm{~m}$. The climate at Solling can be described as sub-oceanic, with a mean annual air temperature of $6.5^{\circ} \mathrm{C}$ and total annual precipitation of $1,090 \mathrm{~mm}$. The prevailing wind direction in the area is SW to W.

Soils at the investigation site are classified as Typic Dystrochrept (USDA) or Dystric Cambisol (FAO) and developed from loess over Triassic sandstone material. The texture is dominated by silt (40-65\%) and sand (35-50\%), the percentage of clay is less than $15 \%$ (for further details see Bolte and Villanueva (2006).

The experimental stand is a mixture of European beech (Fagus sylvatica L.) and Norway spruce (Picea abies (L.) Karst.). According to Bolte and Villanueva (2006) and Oberdorfer (1992) the natural forest community at the site is a Luzulo-Fagetum. Thus, most beech trees that originated from natural regeneration and Norway spruce were planted but are also naturally regenerating at the site. The age of the old growth spruce trees ranged from 90 to 

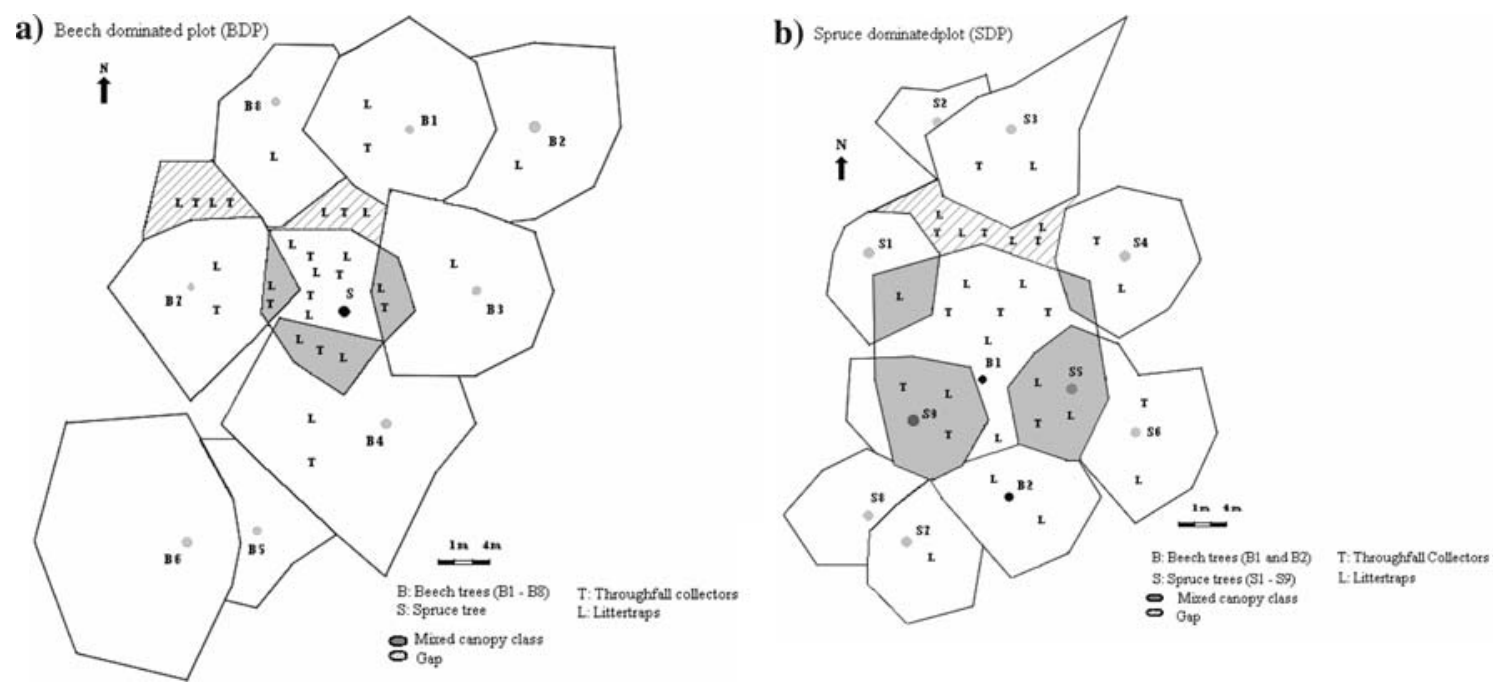

Fig. 1 Canopy projection of the a beech $(B D P)$ and $\mathbf{b}$ spruce $(S D P)$ dominated plot with the locations of throughfall collectors and litter traps

125 years. Beech trees were 125-150 years old. For further details on vegetation and stand structural data see Bolte and Villanueva (2006) and Weckesser (2003). Under pure beech the organic horizon is classified as a more type humus whereas under spruce a raw humus type has developed. Soil $\mathrm{pH}$ values at the site are low, ranging from $\mathrm{pH}$ (KCL) 3.0 in the humus layer and the upper mineral soil horizons to $\mathrm{pH} 4.2$ in the deeper mineral soil horizons. The base saturation at the site is low (below 11\%; Hojjati 2008), but may increase under pure beech stands in this area as reported by Bolte and Villanueva (2006). Due to the high inputs of nitrogen compounds from atmospheric deposition at Solling, $\mathrm{C} / \mathrm{N}$ ratios were relatively low in the organic layers $(\mathrm{C} / \mathrm{N}=26-29)$ and the upper mineral soil horizons $(0-10 \mathrm{~cm}$ soil depth: $\mathrm{C} / \mathrm{N}=17-24$; for further details see Hojjati 2008).

The nutrient content of fresh needle and litter material was not determined within the given study. According to the values reported by Müller-Using and Rademacher (2004) and compared with levels in European forests (Stefan et al. 1997), the nutrient levels in spruce trees growing in mixed stands in Solling are within the range of the second tercile for $\mathrm{N}(12.9-14.9 \mathrm{mg} / \mathrm{g})$, first tercile for $\mathrm{P}$ $(\leq 1.30 \mathrm{mg} / \mathrm{g})$, first tercile for $\mathrm{K}(\leq 5.91 \mathrm{mg} / \mathrm{g})$, second tercile for $\mathrm{Ca}(3.98-5.34 \mathrm{mg} / \mathrm{g})$, first tercile for $\mathrm{Mg}$ $(\leq 1.03 \mathrm{mg} / \mathrm{g})$ and first tercile for $\mathrm{S}(\leq 0.94 \mathrm{mg} / \mathrm{g})$. Nutrient levels in beech trees belongs to the third tercile for $\mathrm{N}$ $(>23.4 \mathrm{mg} / \mathrm{g})$, second tercile for P $(1.15-1.36 \mathrm{mg} / \mathrm{g})$, first tercile for $\mathrm{K}(\leq 7.30 \mathrm{mg} / \mathrm{g})$, first tercile for $\mathrm{Ca}(\leq 9.16 \mathrm{mg} /$ $\mathrm{g})$, first tercile for $\mathrm{Mg}(\leq 1.45 \mathrm{mg} / \mathrm{g})$ and third tercile for $\mathrm{S}$ $(>2.11 \mathrm{mg} / \mathrm{g}$ ).

Our investigation was carried out in two different plots each covering an area of about $300 \mathrm{~m}^{2}$. These plots represented two contrasting cases of mixed forest types, (1) a site greatly dominated by spruce trees-the spruce dominated plot (SDP) with two beech trees in-between (see Fig. 1a) and (2) a directly neighbouring site which was dominated by beech trees and having a single spruce tree in-between-the beech dominated plot (BDP; see Fig. 1b).

The canopy of each plot was classified into four categories: pure spruce, mixed spruce and beech, pure beech and gap. The gap in the BDP was created by the felling of a single beech tree a few years ago while in the SDP; the gap has been the open spaces within the canopy for a long time. Table 1 shows the general characteristics of the studied plots.

Data collection and chemical analysis

\section{Throughfall}

For throughfall sampling 12 collectors with $\varnothing=8 \mathrm{~cm}$ were used in each plot. The collectors were randomly installed in the area under each canopy class approximately $1 \mathrm{~m}$ above forest floor at fixed positions from May 2005 to July 2006. The gauges were placed in the middle of the crown projection and the opening area of the gap to avoid edge effects.

Sampling was carried out 1-2 times a month and samples were combined proportionally to water amounts for monthly samples for analysis. The collectors were replaced by cleaned ones at the end of each month. In snow periods, buckets $(\varnothing=25 \mathrm{~cm})$ replaced the rain collecting gauges. Stemflow of one beech tree in each site was measured monthly in the vegetation period of 2005 (May to October). Due to some technical problems, stemflow could not be collected during winter. 
Table 1 Stand characteristics of the beech (BDP) and spruce (SDP) dominated plot

\begin{tabular}{|c|c|c|c|c|c|c|c|c|}
\hline & \multicolumn{4}{|l|}{$\mathrm{BDP}$} & \multicolumn{4}{|l|}{ SDP } \\
\hline & Spruce & Mixed & Beech & Gap & Spruce & Mixed & Beech & Gap \\
\hline Area per canopy class $\left(\mathrm{m}^{2}\right)(\%)$ & $11(4)$ & $17(6)$ & $231(81)$ & $27(9)$ & $156(56)$ & $45(18)$ & $51(18)$ & $28(10)$ \\
\hline Number of trees & 1 & & 8 & & 9 & & 2 & \\
\hline $\mathrm{DBH}(\mathrm{cm})( \pm \mathrm{SD})$ & 61.4 & & $42.8(8.9)$ & & $67.4(6.8)$ & & $44.2(15.7)$ & \\
\hline Height $(\mathrm{m})( \pm \mathrm{SD})$ & 32.8 & & $28.6(1.8)$ & & $38.2(3.3)$ & & $25.6(5.6)$ & \\
\hline Basal area $\left(\mathrm{m}^{2}\right)( \pm \mathrm{SD})$ & 0.5 & & $0.3(0.1)$ & & $0.5(0.1)$ & & $0.3(0.1)$ & \\
\hline
\end{tabular}

After collection, samples were immediately filtered, stored at $4^{\circ} \mathrm{C}$ and analysed within the following weeks. Chemical analysis of throughfall and stemflow water for $\mathrm{SO}_{4}{ }^{2-}, \mathrm{Na}^{+}, \mathrm{K}^{+}, \mathrm{Ca}^{2+}, \mathrm{Mg}^{2+}, \mathrm{Mn}^{2+}$ was carried out by the Inductive-Coupled Plasma Atomic Emission Spectroscope technique (ICP-AES, Spectroflame, Spectro Analytical Instruments, Kleve, Germany).

$\mathrm{NH}_{4}{ }^{+}$and $\mathrm{NO}_{3}{ }^{-}$were determined by using continuous flow injection colorimetry (Cenco/Skalar Instruments, Breda, The Netherlands). $\mathrm{NH}_{4}{ }^{+}$was determined using the Berthelot reaction method (Skalar Method 155-000), $\mathrm{NO}_{3}{ }^{-}$ was determined using the copper-cadmium reduction method (Skalar Method 461-00). Total nitrogen $\left(\mathrm{N}_{\mathrm{t}}\right)$ was analysed as $\mathrm{NO}_{3}{ }^{-}$after alkaline persulphate and $\mathrm{UV}$ digestion to convert both $\mathrm{NH}_{4}{ }^{+}$and $\mathrm{N}_{\text {org }}$ to $\mathrm{NO}_{3}{ }^{-}$. Organic nitrogen $\left(\mathrm{N}_{\text {org }}\right)$ was computed as: $\mathrm{N}_{\text {org }}=\mathrm{N}_{\mathrm{t}}-\left(\mathrm{NH}_{4}{ }^{+}+\right.$ $\left.\mathrm{NO}_{3}{ }^{-}\right) . \mathrm{Cl}^{-}$was determined by a continuous flow system equipped with an $\mathrm{Ag} / \mathrm{AgCl}$ ion selective electrode. DOC was measured by dry combustion at $680^{\circ} \mathrm{C}$ using a TOC-5050 Shimadzu organic C analyser (Shimadzu Europa, Duisburg, Germany). The $\mathrm{pH}$ was measured in the laboratory with a Microprocessor $\mathrm{pH} /$ Ion Meter PMX 3000 .

\section{Litterfall}

Each plot was equipped with 18 plastic litter traps $(0.5 \times 0.5 \mathrm{~m})$ perforated at the bottom for water drainage. The number of litter traps in the area under each canopy class was 4, 4, 6 and 4 under spruce, mixed, beech canopies and in the gap canopy classes, respectively, in each plot. The traps were distributed randomly and raised about $0.5 \mathrm{~m}$ above the forest floor at fixed positions. Litterfall was collected monthly from May 2005 to July 2006, except from December 2005 to February 2006 (one sampling), because of heavy snow and ice layers in the litter traps.

The collected litter was oven-dried at $60^{\circ} \mathrm{C}$ immediately to constant weight $(48-72 \mathrm{~h})$. The dried materials were sorted manually into the following compartments: leaves, needles, beech branches, spruce branches, a fraction of residual materials, which consisted of bud scales, seeds, seed shells and other fine debris. Thereafter the monthly weight of each fraction in each trap was registered. The materials of animal origin were not included in the subdivided fractions.

Sub-samples of the monthly litter samples were chemically analysed, but only for the leaf and needle fraction. Samples were prepared by grinding the litter to a fine powder and subsequently digested with $2 \mathrm{ml}$ of $\mathrm{HNO}_{3}$ in Teflon digestion bombs $\left(5 \mathrm{~h}, 170^{\circ} \mathrm{C}\right.$; for further description see also Heinrichs 1989). After digestion the concentration of major cations $\left(\mathrm{Na}^{+}, \mathrm{K}^{+}, \mathrm{Ca}^{2+}, \mathrm{Mg}^{2+}, \mathrm{Mn}^{2+}\right)$ as well as total sulphur $\left(\mathrm{S}_{\mathrm{t}}\right)$ and total phosphorus $\left(\mathrm{P}_{\mathrm{t}}\right)$ was determined by the Inductive-Coupled Plasma Atomic Emission Spectroscope technique (ICP-AES, Spectroflame, Spectro Analytical Instruments, Kleve, Germany). The values were recalculated on an oven dry weight $\left(105^{\circ} \mathrm{C}\right)$ basis, which was determined on separate sub-samples. Total nitrogen $\left(\mathrm{N}_{\mathrm{t}}\right)$ and carbon $\left(\mathrm{C}_{\mathrm{t}}\right)$ were determined by a $\mathrm{C} / \mathrm{N}$-analyser (CHN-O-Rapide, VarioEL, Elementar, Germany).

\section{Calculation and statistical analysis}

To estimate the monthly flux of inputs, the concentration of elements in throughfall $(\mathrm{mg} / \mathrm{L})$ or litterfall $(\mathrm{mg} / \mathrm{g})$ on each sampling occasion was multiplied by the amount of water, or mass of leaves and needles litterfall separately for each sampling occasion and month. Annual fluxes in all cases were the sum of 12-month estimated fluxes.

To calculate the rates of canopy leaching of cations $\left(\mathrm{K}^{+}\right.$, $\mathrm{Ca}^{2+}, \mathrm{Mg}^{2+}$ ) for each canopy class, we used the calculation approach developed by Ulrich (Ulrich 1983; Bredemeier 1988; Ulrich 1994). The model assumes that foliar leaching of $\mathrm{Na}^{+}$is small and the ratio of throughfall and bulk precipitation of $\mathrm{Na}^{+}$can be used for determination of base cation leaching from the canopy. Data on the annual amount of bulk precipitation and major element fluxes were available from the long-term monitored plot $F 1$ at Solling which is located about $2 \mathrm{~km}$ from our plots (Meesenburg 2006, personal communication). According to these data the bulk precipitation at the site is characterised by higher fluxes of most of the elements (but not for $\mathrm{K}^{+}$and $\mathrm{Mn}^{2+}$ ) during the leafless period compared with the rest of the year (Table 2). 
Table 2 Mean annual water and element fluxes $( \pm$ SD) of bulk precipitation $(n=3)$ from F1 plot in Solling according to Meesenburg $(2006$, personal communication)

\begin{tabular}{lllllllllllll}
\hline & $\begin{array}{l}\text { Water } \\
(\mathrm{mm})\end{array}$ & $\mathrm{pH}$ & $\mathrm{Na}^{+}$ & $\mathrm{K}^{+}$ & $\begin{array}{l}\mathrm{Ca}^{2+} \\
\left(\mathrm{g} / \mathrm{m}^{2}\right)\end{array}$ & $\mathrm{Mg}^{2+}$ & $\mathrm{Mn}^{2+}$ & $\mathrm{NH}_{4}^{+}$ & $\mathrm{NO}_{3}{ }^{-}$ & $\mathrm{SO}_{4}{ }^{2-}$ & $\mathrm{Cl}^{-}$ & \\
\hline Annual & $1112(6.8)$ & $5.04(0.02)$ & $0.65(0.01)$ & $0.12(0.01)$ & $0.17(0.0)$ & $0.06(0.0)$ & $0.0(0.0)$ & $0.73(0.0)$ & $0.60(0.01)$ & $0.56(0.0)$ & $1.01(0.03)$ \\
Summer & $496(3.1)$ & $5.02(0.01)$ & $0.20(0.01)$ & $0.07(0.01)$ & $0.07(0.0)$ & $0.02(0.0)$ & $0.0(0.0)$ & $0.27(0.0)$ & $0.22(0.0)$ & $0.23(0.01)$ & $0.22(0.01)$ \\
Winter & $616(3.8)$ & $5.05(0.02)$ & $0.45(0.0)$ & $0.05(0.0)$ & $0.10(0.0)$ & $0.04(0.0)$ & $0.0(0.0)$ & $0.46(0.0)$ & $0.38(0.0)$ & $0.37(0.0)$ & $0.79(0.02)$ \\
\hline
\end{tabular}

We applied statistics only for comparing water and element fluxes (via throughfall and litterfall) between canopy categories within each plot. The one-way analysis of variance (ANOVA) was used after checking the assumptions for parametric test applications. The variables with non-parametric distribution were transformed to achieve normal distribution and homogeneous variances. Turkey's HSD test was used to determine significant differences at the level of $P<0.05$. SPSS, version 9.0 for Windows, was used for statistical analysis.

For comparing water and element fluxes for the same canopy categories between the two plots the ratios between the absolute values of these fluxes (SDP to BDP) were used instead of statistical analysis. The influence of beech and spruce admixture on litter quality was only analysed on the plot level, i.e. arithmetic means of element concentrations were statistically (Student's $t$ test) compared between SDP and BDP without considering canopy classes.

\section{Results}

\section{Throughfall}

The annual throughfall water fluxes in different canopy classes in both plots followed the same pattern and tended to decrease in the order gap $>$ mixed $>$ beech $>$ spruce but showed significant difference only between gap and spruce. In the SDP, in addition, the annual water flux under spruce differed significantly from the water fluxes under the beech and mixed canopies. The amounts of annual throughfall water in all canopy classes were higher in the BDP than corresponding canopy classes in the SDP; these differences were highest under the spruce canopies $(34 \%)$ and lowest under the beech canopies $(10 \%)$, as shown in Table 3 . In both plots, throughfall amounts were significantly higher in the leafless period (November to April) in all canopy classes compared to the leafed period (May to October) due to higher

Table 3 Mean $( \pm \mathrm{SD})$ annual water and element fluxes via throughfall in different canopy classes of the beech $(B D P)$ and spruce $(S D P)$ dominated plot $\left(\mathrm{g} / \mathrm{m}^{-2}\right.$ year $\left.^{-1}\right)$

\begin{tabular}{|c|c|c|c|c|c|c|c|c|}
\hline & \multicolumn{4}{|l|}{ BDP } & \multicolumn{4}{|l|}{ SDP } \\
\hline & $\begin{array}{l}\text { Spruce } \\
n=3\end{array}$ & $\begin{array}{l}\text { Mixed } \\
n=3\end{array}$ & $\begin{array}{l}\text { Beech } \\
n=3\end{array}$ & $\begin{array}{l}\text { Gap } \\
n=3\end{array}$ & $\begin{array}{l}\text { Spruce } \\
n=3\end{array}$ & $\begin{array}{l}\text { Mixed } \\
n=3\end{array}$ & $\begin{array}{l}\text { Beech } \\
n=3\end{array}$ & $\begin{array}{l}\text { Gap } \\
n=3\end{array}$ \\
\hline Water* & $578.6(81.7)$ a & $667.0(27.7) \mathrm{ab}$ & $616.3(19.6) \mathrm{ab}$ & $703.2(27.0) \mathrm{b}$ & $432.3(23.3) \mathrm{a}$ & $566.3(32.0) \mathrm{b}$ & $562.1(24.0) \mathrm{b}$ & $611.4(11.6) \mathrm{b}$ \\
\hline $\mathrm{pH}$ & $5.7(0.10)$ & $5.8(0.05)$ & $6.1(0.20)$ & $5.7(0.06)$ & $5.4(0.05)$ & $5.5(0.15)$ & $5.8(0.30)$ & $5.6(0.05)$ \\
\hline $\mathrm{Na}^{+}$ & $2.07(0.03) \mathrm{c}$ & $1.60(0.10) b$ & $0.89(0.19) \mathrm{a}$ & $0.93(0.06) \mathrm{a}$ & $1.78(0.23) \mathrm{b}$ & $1.73(0.17) \mathrm{b}$ & $0.80(0.07) \mathrm{a}$ & $1.05(0.09) \mathrm{a}$ \\
\hline $\mathrm{K}^{+}$ & $2.63(0.41) b c$ & $3.03(0.07) \mathrm{c}$ & $2.04(0.34) \mathrm{b}$ & $1.11(0.33) \mathrm{a}$ & $2.42(0.22) \mathrm{b}$ & $3.22(0.31) \mathrm{c}$ & $1.42(0.06) \mathrm{a}$ & $1.41(0.10) \mathrm{a}$ \\
\hline $\mathrm{Ca}^{2+}$ & $1.18(0.13) \mathrm{c}$ & $0.95(0.03) \mathrm{b}$ & $0.62(0.08) \mathrm{a}$ & $0.43(0.14) \mathrm{a}$ & $1.43(0.04) \mathrm{b}$ & $1.43(0.23) \mathrm{b}$ & $0.59(0.04) \mathrm{a}$ & $0.80(0.16) \mathrm{a}$ \\
\hline $\mathrm{Mg}^{2+}$ & $0.45(0.03) \mathrm{d}$ & $0.38(0.02) \mathrm{c}$ & $0.28(0.03) \mathrm{b}$ & $0.21(0.02) \mathrm{a}$ & $0.47(0.03) \mathrm{b}$ & $0.52(0.11) b$ & $0.20(0.02) \mathrm{a}$ & $0.27(0.03) \mathrm{a}$ \\
\hline $\mathrm{Mn}^{2+}$ & $0.33(0.03) \mathrm{c}$ & $0.27(0.02) b c$ & $0.25(0.02) \mathrm{b}$ & $0.14(0.02) \mathrm{a}$ & $0.44(0.02) \mathrm{b}$ & $0.52(0.15) \mathrm{b}$ & $0.12(0.01) \mathrm{a}$ & $0.19(0.03) \mathrm{a}$ \\
\hline $\mathrm{NH}_{4}^{+}$ & $1.52(0.16) \mathrm{c}$ & $1.17(0.15) \mathrm{b}$ & $0.77(0.06) \mathrm{a}$ & $0.71(0.06) \mathrm{a}$ & $1.59(0.14) \mathrm{b}$ & $1.42(0.08) \mathrm{b}$ & $0.83(0.20) \mathrm{a}$ & $0.99(0.05) \mathrm{a}$ \\
\hline $\mathrm{NO}_{3}^{-}$ & $1.76(0.14) \mathrm{c}$ & $1.22(0.12) \mathrm{b}$ & $0.61(0.08) \mathrm{a}$ & $0.65(0.02) \mathrm{a}$ & $1.40(0.03) \mathrm{b}$ & $1.61(0.25) \mathrm{b}$ & $0.68(0.20) \mathrm{a}$ & $0.88(0.03) \mathrm{a}$ \\
\hline $\mathrm{SO}_{4}{ }^{2-}$ & $1.59(0.21) \mathrm{c}$ & $1.25(0.03) \mathrm{b}$ & $0.80(0.09) \mathrm{a}$ & $0.69(0.04) \mathrm{a}$ & $1.89(0.03) \mathrm{b}$ & $1.97(0.27) \mathrm{b}$ & $0.81(0.05) \mathrm{a}$ & $1.05(0.08) \mathrm{a}$ \\
\hline $\mathrm{Cl}^{-}$ & $4.32(0.34) \mathrm{c}$ & $3.20(0.21) b$ & $1.92(0.36) \mathrm{a}$ & $1.84(0.20) \mathrm{a}$ & $3.83(0.19) \mathrm{b}$ & $3.99(0.49) \mathrm{b}$ & $1.84(0.15) \mathrm{a}$ & $2.33(0.16) \mathrm{a}$ \\
\hline DOC & $10.5(0.84) \mathrm{d}$ & $7.84(0.31) c$ & $5.67(0.64) b$ & $3.61(0.81) \mathrm{a}$ & $13.1(0.86) \mathrm{b}$ & $11.8(0.76) \mathrm{b}$ & $6.10(0.29) \mathrm{a}$ & $7.46(0.61) \mathrm{a}$ \\
\hline $\mathrm{N}_{\text {org }}$ & $0.44(0.05) \mathrm{c}$ & $0.33(0.04) b$ & $0.23(0.03) \mathrm{a}$ & $0.16(0.02) \mathrm{a}$ & $0.45(0.04) \mathrm{c}$ & $0.39(0.09) \mathrm{bc}$ & $0.27(0.12) a b$ & $0.25(0.03) \mathrm{a}$ \\
\hline
\end{tabular}

$* \mathrm{~mm}=\mathrm{L} / \mathrm{m}^{2}$

Values in brackets indicate the standard deviation $( \pm \mathrm{SD})$

Different letters indicate significant $(P<0.05)$ differences on the plot level. No letter means no significant difference 

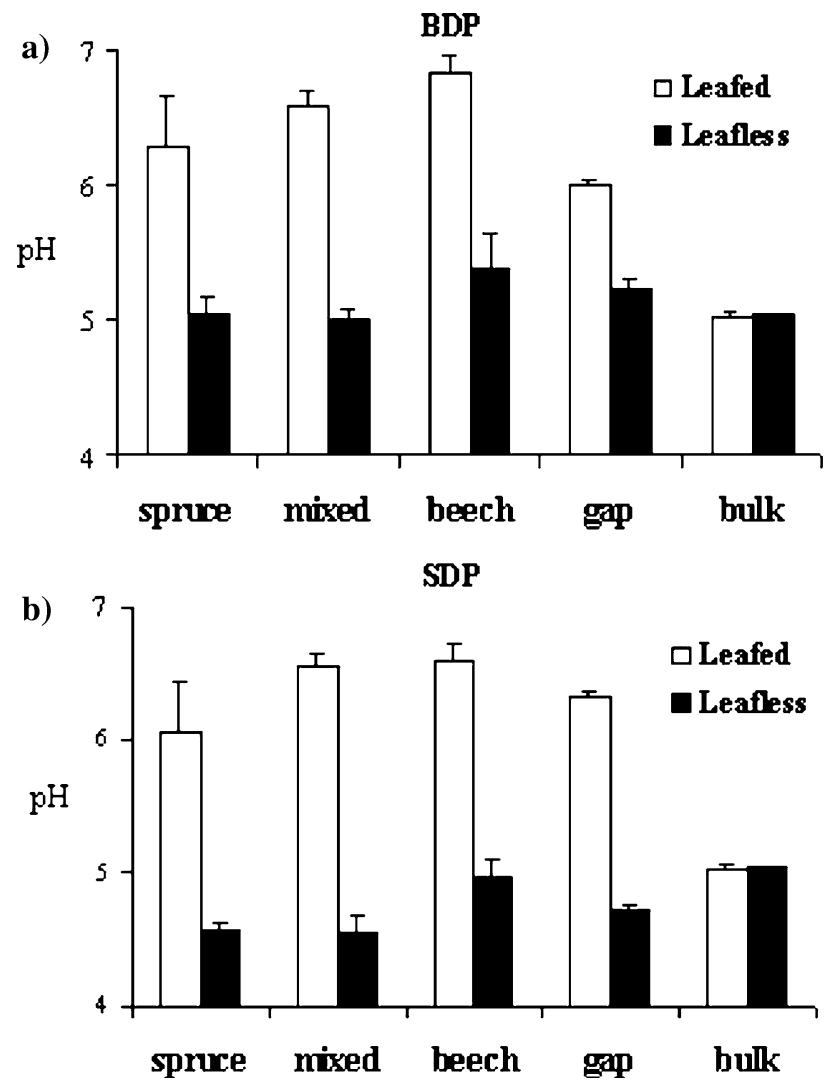

Fig. 2 Mean $\mathrm{pH}$ values $( \pm \mathrm{SD})$ of throughfall in leafed and leafless periods in different canopy classes of the $\mathbf{a}$ beech $(B D P)$ and $\mathbf{b}$ spruce $(S D P)$ dominated plot and in bulk precipitation

precipitation (see Table 2) and less interception loss during winter period (data not shown).

The annual $\mathrm{pH}$ values of throughfall under beech canopy classes in both plots tended to be higher than those under other canopy categories, but the differences were not significant due to wide variation (Table 3). In the BDP the $\mathrm{pH}$ values were higher under spruce and mixed canopies compared with the same canopy categories in the SDP (Table 3). Seasonal variability of $\mathrm{pH}$ was observed in both plots. The $\mathrm{pH}$ values of throughfall in the leafless period were lower, but they were higher (more than 1 unit) in the leafed period compared to the $\mathrm{pH}$ of bulk precipitation, especially in the SDP (Fig. 2a, b).

In the SDP, the annual fluxes of all elements with the exception of $\mathrm{K}^{+}, \mathrm{N}_{\mathrm{org}}$ and DOC followed the order: spruce $=$ mixed $>$ beech $=$ gap. In the BDP, for most of the elements $\left(\mathrm{Ca}^{2+}, \mathrm{NO}_{3}{ }^{-}, \mathrm{NH}_{4}{ }^{+}, \mathrm{N}_{\text {org }}, \mathrm{SO}_{4}{ }^{2-}, \mathrm{Na}^{+}, \mathrm{Cl}^{-}\right)$the differences between spruce and other canopy categories were more pronounced, resulting in the following pattern: spruce $>$ mixed $>$ beech $=$ gap. For $\mathrm{Mg}^{2+}$ and DOC in this plot there were, in addition, found significant differences a) BDP
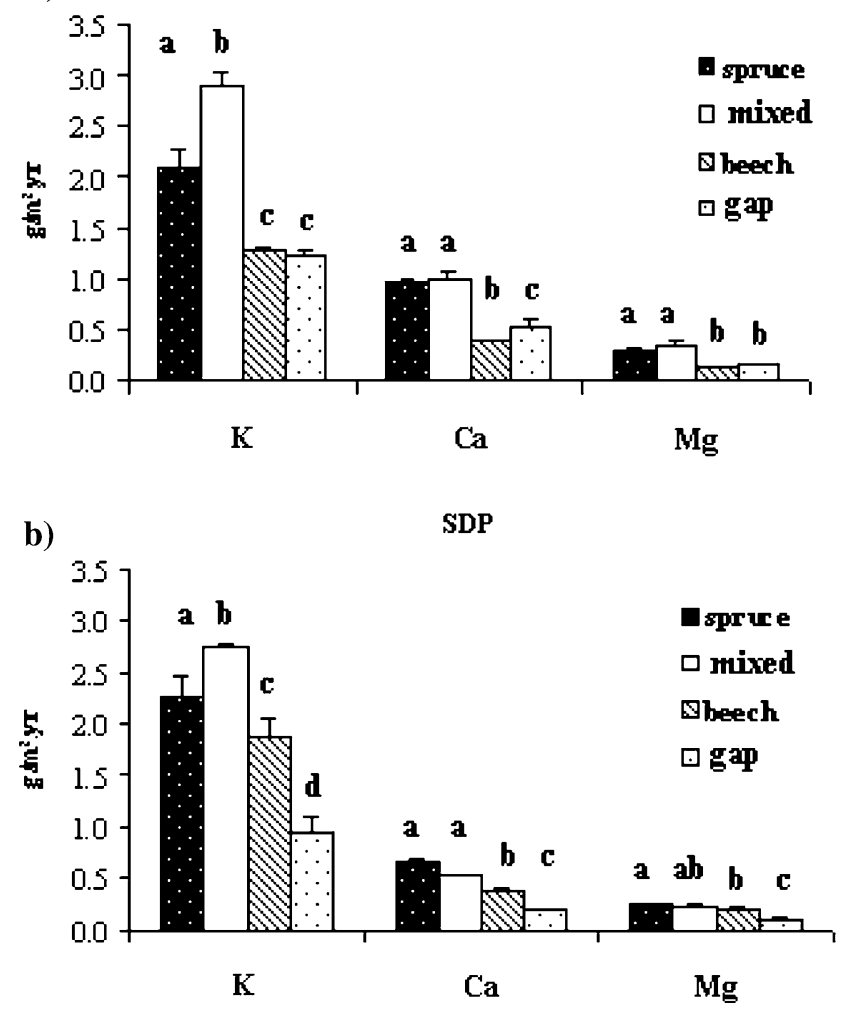

Fig. 3 Mean $( \pm \mathrm{SD})$ annual canopy leaching of base cations from different canopy classes-for the a beech $(B D P)$ and $\mathbf{b}$ spruce $(S D P)$ dominated plot. Different letters indicate significant $(P<0.05)$ differences

between beech and gap. $\mathrm{Mn}^{2+}$ followed the same pattern as most of the elements but the mixed canopy did not show any differences compared with the spruce and beech canopy classes. The fluxes of $\mathrm{K}^{+}$in both plots were highest under the mixed canopy, although in the BDP the fluxes of potassium under spruce and mixed canopy significantly $(P<0.05)$. In the BDP, the $\mathrm{K}^{+}$flux in the gap was appreciably lower than under other canopy classes, while in the SDP the corresponding flux in the gap and under beech canopy were the same.

The calculation of base cations leaching from different canopy classes based on the Ulrich model (1983) showed that $\mathrm{K}^{+}$leaching in both plots was highest under mixed canopy classes. The leached amounts of base cations $\left(\mathrm{K}^{+}\right.$, $\mathrm{Ca}^{2+}, \mathrm{Mg}^{2+}$ ) were significantly higher under spruce than under beech canopy in both plots. In the BDP, the gap class exhibited by far the lowest amounts of cation input by leaching (Fig. 3a), while in the SDP we found no significant differences in leached amounts of $\mathrm{K}^{+}$and $\mathrm{Mg}^{2+}$ between gap and beech, and the canopy leaching of $\mathrm{Ca}^{2+}$ in the gap was also significantly greater than under beech (Fig. 3b). 
Table 4 Mean $( \pm \mathrm{SD})$ annual mass of different litterfall compartments in different canopy classes of the beech (BDP) and spruce (SDP) dominated plot (g/ $\mathrm{m}^{-1}$ year $^{-1}$ )

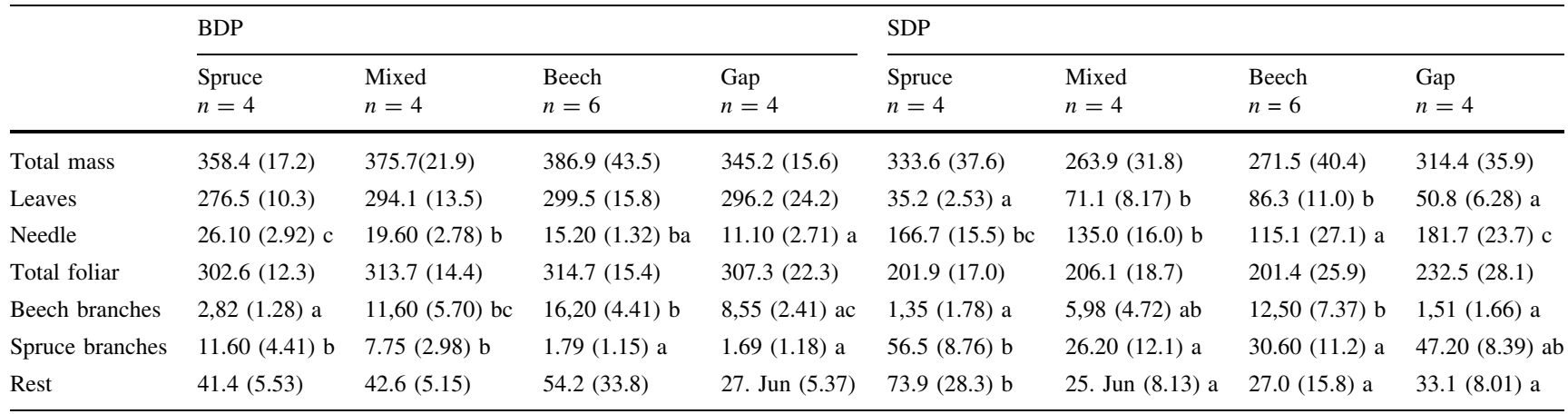

Values in brackets indicate the standard deviation $( \pm \mathrm{SD})$

Different letters indicate significant $(P<0.05)$ differences on the plot level. No letter means no significant difference

\section{Litterfall}

The amounts of total litterfall under different canopy classes in the BDP tended to decrease in the order beech $>$ mixed $>$ spruce $>$ gap and in the order spruce $>$ gap $>$ beech $>$ mixed in the SDP, but the differences were not significant (Table 4).

The main fraction of litterfall was foliar litter in both plots, which represented $80-90$ and $60-80 \%$ of total litterfall amount in the BDP and SDP, respectively (Table 4). With respect to canopy classes we found no significant difference in beech leaf litter production in the BDP, but in the SDP the significantly highest amounts of beech leaf litterfall were recorded under the beech and mixed canopy classes. The fluxes of needle litter under different canopy classes in the BDP tended to decrease in the order: spruce $>$ mixed $\geq$ beech $\geq$ gap with a significantly greater amount under spruce compared to other canopy classes (Table 4). In the SDP, the higher amounts of needle litter were found in gaps and under the spruce canopies, resulting in the following order: gap $\geq$ spruce $\geq$ mixed $>$ beech (Table 4 ).

Regardless of the canopy classes, the mean concentrations of potassium, calcium and manganese in leaf and needle litter (Fig. 4) produced in the BDP were significantly higher than in the litter produced in the SDP. The concentrations of $\mathrm{N}$ in beech foliar litter were higher in the SDP than in the BDP, while spruce foliar litter showed no differences between the plots $(P<0.05)$. The concentration of all other elements exhibited no significantly differences in both leaf and needle litter fractions between the two plots.

A comparison of annual element fluxes via foliage litterfall among different canopy classes in the BDP did not indicate any significant differences $(P<0.05)$ for any of the considered elements (Table 5).

In the SDP, the annual return of $\mathrm{Mg}$ to the forest floor via foliar litterfall was lower under the spruce canopy than
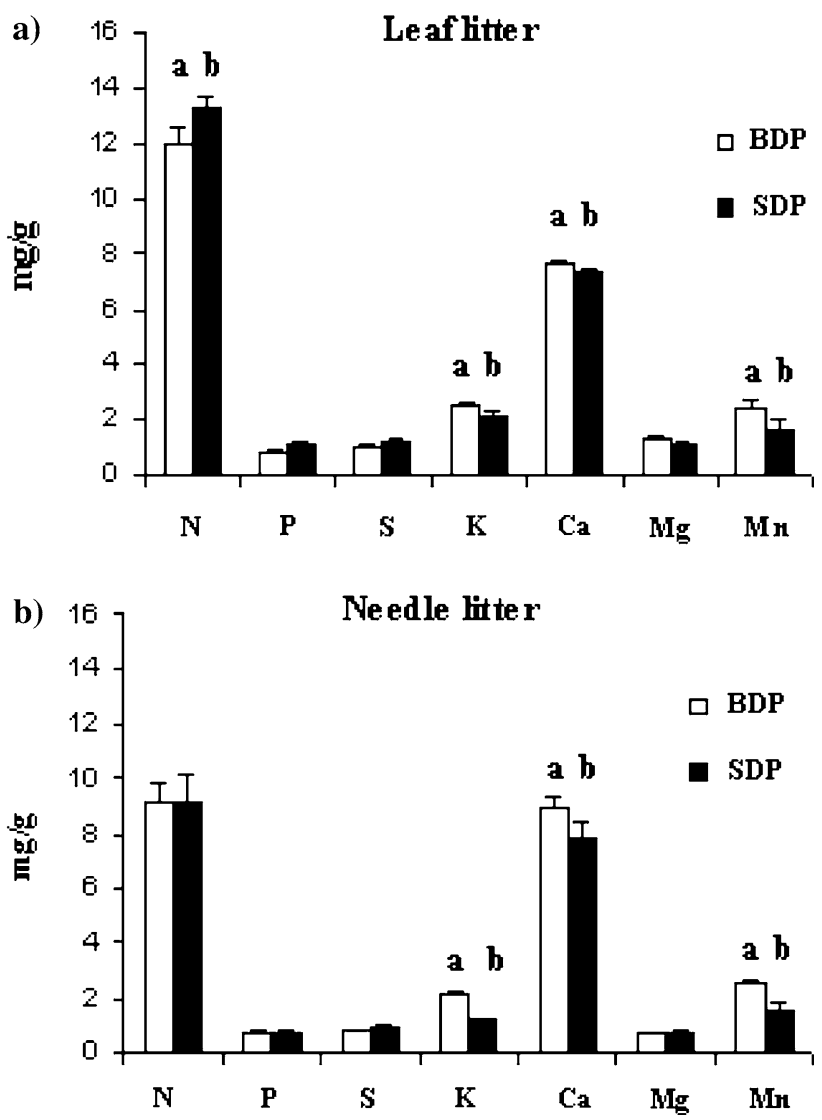

Fig. 4 Mean $( \pm$ SD) element concentration in leaf (a) and needle (b) litter in the beech and spruce-dominated plots. Different letters indicate significant $(P<0.05)$ differences

under the beech and mixed canopies, while other elements showed no significant differences under different types of canopies (Table 5). The amount of total foliar litterfall was higher in the BDP than in the SDP and considerably higher annual fluxes of elements via litterfall under all canopy 
Table 5 Mean $( \pm$ SD) annual mass and element fluxes via foliar litterfall in different canopy classes of the beech (BDP) and spruce (SDP) dominated plot $\left(\mathrm{g} / \mathrm{m}^{-2}\right.$ year $\left.^{-1}\right)$

\begin{tabular}{|c|c|c|c|c|c|c|c|c|}
\hline & \multicolumn{4}{|l|}{ BDP } & \multicolumn{4}{|l|}{ SDP } \\
\hline & $\begin{array}{l}\text { Spruce } \\
n=4\end{array}$ & $\begin{array}{l}\text { Mixed } \\
n=4\end{array}$ & $\begin{array}{l}\text { Beech } \\
n=6\end{array}$ & $\begin{array}{l}\text { Gap } \\
n=4\end{array}$ & $\begin{array}{l}\text { Spruce } \\
n=4\end{array}$ & $\begin{array}{l}\text { Mixed } \\
n=4\end{array}$ & $\begin{array}{l}\text { Beech } \\
n=6\end{array}$ & $\begin{array}{l}\text { Gap } \\
n=4\end{array}$ \\
\hline Mass & $302.6(12.3)$ & $313.7(14.4)$ & $314.7(15.4)$ & 307.3 (22.3) & 201.9 (17.0) & 206.1 (18.7) & $201.4(25.9)$ & $232.5(28.1)$ \\
\hline $\mathrm{Na}$ & $0.05(0.00)$ & $0.05(0.00)$ & $0.05(0.01)$ & $0.04(0.00)$ & $0.02(0.00)$ & $0.03(0.01)$ & $0.02(0.00)$ & $0.03(0.00)$ \\
\hline K & $0.74(0.05)$ & $0.77(0.06)$ & $0.82(0.08)$ & $0.75(0.04)$ & $0.27(0.04)$ & $0.29(0.07)$ & $0.30(0.05)$ & $0.32(0.06)$ \\
\hline $\mathrm{Ca}$ & $2.43(0.13)$ & $2.54(0.14)$ & $2.51(0.18)$ & $2.43(0.22)$ & $1.58(0.36)$ & $1.67(0.18)$ & $1.56(0.14)$ & $1.77(0.36)$ \\
\hline $\mathrm{Mg}$ & $0.36(0.02)$ & $0.40(0.02)$ & $0.40(0.02)$ & $0.39(0.04)$ & $0.14(0.01) \mathrm{a}$ & $0.19(0.02) \mathrm{b}$ & $0.19(0.03) \mathrm{b}$ & $0.17(0.02) a b$ \\
\hline $\mathrm{Mn}$ & $0.76(0.03)$ & $0.80(0.04)$ & $0.82(0.06)$ & $0.79(0.07)$ & $0.33(0.08)$ & $0.30(0.06)$ & $0.28(0.02)$ & $0.38(0.11)$ \\
\hline $\mathrm{S}$ & $0.28(0.01)$ & $0.28(0.02)$ & $0.29(0.02)$ & $0.28(0.02)$ & $0.19(0.02)$ & $0.20(0.02)$ & $0.20(0.03)$ & $0.21(0.02)$ \\
\hline $\mathrm{P}$ & $0.24(0.02)$ & $0.22(0.02)$ & $0.22(0.01)$ & $0.21(0.01)$ & $0.16(0.02)$ & $0.18(0.02)$ & $0.18(0.02)$ & $0.18(0.02)$ \\
\hline $\mathrm{N}$ & $2.95(0.10)$ & $2.99(0.21)$ & $3.05(0.08)$ & $2.99(0.25)$ & $1.93(0.14)$ & $2.10(0.13)$ & $2.10(0.32)$ & $2.16(0.17)$ \\
\hline $\mathrm{C}$ & $156.6(6.39)$ & $162.3(7.0)$ & $163.8(8.1)$ & $160.1(11.5)$ & $105.7(10.2)$ & $105.1(9.09)$ & $103.3(13.1)$ & $119.2(14.2)$ \\
\hline
\end{tabular}

Values in brackets indicate the standard deviation $( \pm \mathrm{SD})$

Different letters indicate significant $(P<0.05)$ differences on the plot level. No letter means no significant difference

classes were recorded in the BDP compared to the corresponding values in the SDP (Table 5).

Total element fluxes

The contribution of litterfall and throughfall to transport elements from the canopy to the soil differed for different elements. In both plots, throughfall was the main pathway for sodium, potassium and sulphur but for calcium the major pathway was litterfall. For nitrogen and magnesium litterfall and throughfall made a relatively similar contribution to the total nutrient inputs. For most elements, the contribution of throughfall in all canopy classes was greater in the SDP than in the BDP. The total inputs of all elements, with the exception of sulphur for all canopy categories and for $\mathrm{Na}$ in gaps, were higher in the BDP than in the SDP.

Spruce and mixed canopy classes showed the highest total inputs for all the studied elements in both plots. The total inputs of $\mathrm{K}$ in mixed canopy classes were considerably higher than under spruce canopy and under the other canopy categories (Table 6).

\section{Discussion}

\section{Throughfall}

Our results showed that throughfall fluxes of most of the elements were considerably higher under the canopy of spruce than beech. The total water fluxes, on the other hand, tended to be higher under the beech canopy than under the canopy of spruce in both plots. The differences in total element fluxes between spruce and beech canopy classes cannot, therefore, be caused by differences in water fluxes under the two species, but reflect differences in their canopy properties. Higher filtering capacity of spruce canopy and higher foliage longevity compared with beech have been pointed out as the main reasons for higher element fluxes in throughfall under spruce (Augusto and Ranger 2001; Rothe et al. 2002a).

The tendency of higher $\mathrm{pH}$ values under the beech canopy compared with spruce and seasonal variability of $\mathrm{pH}$ values under different canopy classes can be explained by different rates of $\mathrm{H}^{+}$buffering process and ion exchange reaction in the canopies (Stachurski and Zimka 2002). The great ability of beech foliage to reduce $\mathrm{H}^{+}$ion concentration in throughfall has been pointed out by Staelens et al. (2006).

The fluxes of $\mathrm{NH}_{4}{ }^{+}, \mathrm{NO}_{3}{ }^{-}$and $\mathrm{SO}_{4}{ }^{2-}$ in throughfall were about twofold higher under the canopy of spruce than beech. Similar results were reported by earlier works in pure and mixed beech-spruce stands (Rothe et al. 2002a; Oulehle and Hruška 2005).

Thus the interspecific differences between spruce and beech canopies observed in our study were in agreement with previous comparative studies in pure beech and spruce stands (Nihlgård 1970; Růžička 1994; Meesenburg et al. 1995; Rothe et al. 2002a; Oulehle and Hruška 2005). Moreover, spruce and beech canopy classes showed the same pattern of differences in two contrasting types of mixture in our investigation. This indicates that canopies of beech and spruce might show the same species-related differences in mixed stands of various beech-spruce proportions. Studies of the throughfall under different species 
Table 6 Total annual input of elements via throughfall (TF) and litterfall (LF) in different canopy classes in beech (BDP) and spruce (SDP) dominated plot $\left(\mathrm{g} / \mathrm{m}^{-2}\right.$ year $\left.^{-1}\right)$

\begin{tabular}{|c|c|c|c|c|c|c|c|c|c|c|c|c|}
\hline & \multicolumn{3}{|l|}{ Spruce } & \multicolumn{3}{|l|}{ Mixed } & \multicolumn{3}{|l|}{ Beech } & \multicolumn{3}{|l|}{ Gap } \\
\hline & $\left(\mathrm{g} / \mathrm{m}^{-2}\right.$ year $\left.^{-1}\right)$ & $\mathrm{TF}$ & LF & $\left(\mathrm{g} / \mathrm{m}^{-2}\right.$ year $\left.^{-1}\right)$ & $\mathrm{TF}$ & LF & $\left(\mathrm{g} / \mathrm{m}^{-2}\right.$ year $\left.^{-1}\right)$ & $\mathrm{TF}$ & LF & $\left(\mathrm{g} / \mathrm{m}^{-2}\right.$ year $\left.^{-1}\right)$ & $\mathrm{TF}$ & LF \\
\hline \multicolumn{13}{|c|}{$B D P$} \\
\hline $\mathrm{Na}$ & 2.1 & 98 & 2 & 1.7 & 97 & 3 & 1.0 & 95 & 5 & 1.0 & 96 & 4 \\
\hline K & 3.4 & 78 & 22 & 3.8 & 80 & 20 & 2.9 & 72 & 28 & 1.9 & 60 & 40 \\
\hline $\mathrm{Ca}$ & 3.6 & 33 & 67 & 3.5 & 27 & 73 & 3.1 & 20 & 80 & 2.9 & 15 & 85 \\
\hline $\mathrm{Mg}$ & 0.8 & 56 & 44 & 0.8 & 49 & 51 & 0.7 & 62 & 38 & 0.6 & 35 & 65 \\
\hline S & 1.9 & 82 & 18 & 1.5 & 82 & 18 & 1.1 & 74 & 26 & 1.0 & 71 & 29 \\
\hline $\mathrm{N}$ & 6.7 & 56 & 44 & 5.7 & 48 & 52 & 4.7 & 35 & 65 & 4.5 & 34 & 66 \\
\hline $\mathrm{C}$ & 167 & 6 & 94 & 170 & 5 & 95 & 170 & 3 & 97 & 164 & 2 & 98 \\
\hline \multicolumn{13}{|l|}{$S D P$} \\
\hline $\mathrm{Na}$ & 1.8 & 99 & 1 & 1.8 & 98 & 2 & 0.8 & 96 & 4 & 1.1 & 97 & 3 \\
\hline K & 2.7 & 90 & 10 & 3.5 & 92 & 8 & 1.7 & 85 & 15 & 1.7 & 82 & 18 \\
\hline $\mathrm{Ca}$ & 3.0 & 48 & 52 & 3.1 & 46 & 54 & 2.2 & 28 & 72 & 2.6 & 31 & 69 \\
\hline $\mathrm{Mg}$ & 0.6 & 77 & 23 & 0.7 & 73 & 27 & 0.4 & 51 & 49 & 0.4 & 61 & 39 \\
\hline S & 2.1 & 91 & 9 & 2.2 & 91 & 9 & 1.0 & 80 & 20 & 1.3 & 83 & 17 \\
\hline $\mathrm{N}$ & 5.4 & 64 & 36 & 5.5 & 62 & 38 & 3.8 & 45 & 55 & 4.3 & 50 & 50 \\
\hline C & 119 & 11 & 89 & 117 & 10 & 90 & 110 & 6 & 94 & 127 & 6 & 94 \\
\hline
\end{tabular}

$\mathrm{TF}$ and LF represent the contribution percents of throughfall and litterfall to total annual input elements

$\mathrm{S}=\mathrm{SO}_{4}-\mathrm{S}_{\text {Throughfall }}+\mathrm{St}_{\text {Litterfall }}$

$\mathrm{N}=\left(\mathrm{NH}_{4}-\mathrm{N}+\mathrm{NO}_{3}-\mathrm{N}+\mathrm{N}_{\text {org }}-\mathrm{N}\right)_{\text {Throughfall }}+\mathrm{Nt}_{\text {Litterfall }}$

$\mathrm{C}=\mathrm{DOC}_{\text {Throughfall }}+\mathrm{Ct}_{\mathrm{Litterfall}}$

growing in mixtures are rare. To our knowledge there is no published study on differences in throughfall chemistry under beech and spruce crowns in a mixed forest. Wilpert (personal communications) did not find any significant differences in nutrient concentrations in throughfall under spruce growing in monocultures and in admixture with beech. Rothe and Binkley (2001) suggested that the nutrient inputs with atmospheric deposition would not vary for the same species in monocultures and mixtures.

On the other hand, the influence of the dominating species on the water and element fluxes in gaps, under mixed canopies and also under the canopy of admixed species were also observed in our study. As spruce, compared with beech, has higher element fluxes in throughfall and lower amounts of water, this influence can be seen when comparing the fluxes of water and elements for the corresponding canopy classes in the SDP and BDP. Table 7 shows the SDP/BDP ratios for different canopy classes. The impact of the dominating species were more pronounced in mixed and gap canopy classes as the ratios were higher than 1 for all of the elements. The fluxes in pure beech and pure spruce canopy classes in the two plots were relatively similar and for some of the elements the ratios were lower than 1 , which might be related to the differences in throughfall water fluxes $(25 \%$ lower in the SDP) and to the possible differences in foliar nutrient status of trees in the two plots. Our plots represent two widely contrasting types of beech/spruce mixtures in terms of the proportional contribution of each of the species. In a mixed stand with a more balanced tree composition the differences between the canopies of spruce and beech might be even more similar to the interspecific differences between beech and spruce observed in monocultures.

Spruce canopy with more circular and symmetric architecture may create more systematic spatial variability in throughfall compared with beech canopy, which has a more heterogeneous crown structure (Beier et al. 1993; Hansen 1995; Seiler and Matzner 1995; Whelan et al. 1998; Zirlewagen and von Wilpert 2001; Staelens et al. 2006). In our study the throughfall in the BDP gap showed more similarities with the throughfall of the dominating species. At the same time spruce as an admixed species caused more heterogeneity in throughfall samples under different canopy classes than beech in the SDP. This indicates the higher capacity of a spruce tree to influence throughfall patterns in a beech-dominated stand compared to the effect of a beech tree in a spruce-dominated site.

In both plots the water and element fluxes via throughfall under the mixed canopies showed values which were similar or intermediate (particularly for the BDP) between the values for beech and spruce canopies. However, for $\mathrm{K}^{+}$ the pattern was substantially different. The annual fluxes of 
Table 7 The SDP/BDP ratio of water and element fluxes via throughfall for different canopy classes

\begin{tabular}{lllll}
\hline & Spruce & Mixed & Beech & Gap \\
\hline Water & 0.7 & 0.8 & 0.9 & 0.9 \\
$\mathrm{H}^{+}$ & 1.6 & 1.6 & 1.5 & 1.2 \\
$\mathrm{Na}^{+}$ & 0.9 & 1.1 & 0.9 & 1.1 \\
$\mathrm{~K}^{+}$ & 0.9 & 1.1 & 0.7 & 1.3 \\
$\mathrm{Ca}^{2+}$ & 1.2 & 1.5 & 1.0 & 1.9 \\
$\mathrm{Mg}^{2+}$ & 1.0 & 1.4 & 0.7 & 1.3 \\
$\mathrm{Mn}^{2+}$ & 1.3 & 1.9 & 0.5 & 1.4 \\
$\mathrm{NH}_{4}{ }^{+}-\mathrm{N}$ & 1.0 & 1.2 & 1.1 & 1.4 \\
$\mathrm{NO}_{3}{ }^{-}-\mathrm{N}$ & 0.8 & 1.3 & 1.1 & 1.4 \\
$\mathrm{SO}_{4}{ }^{2-}-\mathrm{S}$ & 1.2 & 1.6 & 1.0 & 1.5 \\
$\mathrm{Cl}^{-}$ & 0.9 & 1.2 & 1.0 & 1.3 \\
$\mathrm{DOC}^{-}$ & 1.2 & 1.5 & 1.1 & 2.1 \\
$\mathrm{Norg}^{-}$ & 1.0 & 1.2 & 1.2 & 1.5 \\
\hline
\end{tabular}

$\mathrm{K}^{+}$under the mixed canopies in both plots were considerably higher than the fluxes under spruce and beech canopies. If we assume that the beech and spruce canopy classes were mixed at the ratio of $1: 1$, the simple summation of throughfall input cannot represent the values found in the mixed classes. The high inputs of $\mathrm{K}^{+}$under mixed canopy may be related to the overlapping of spruce and beech canopies, the creation of dense foliage and the interaction between the canopies of the two species. The spruce trees in both plots were taller than the beech trees, so the rainfall water first passed through the spruce canopy, which is characterised by high interception capacity, and then the canopy of beech with its high susceptibility to leaching. The separate calculation of $\mathrm{K}^{+}$amounts in throughfall depending on the season has shown that the fluxes of $\mathrm{K}^{+}$were higher in mixed canopy categories even in the leafless period. During this period the $\mathrm{pH}$ of throughfall under the spruce canopy in our investigation tended to be lower in the leafless part of the year than the $\mathrm{pH}$ of bulk precipitation, particularly in the SDP plot (Fig. 3). Since potassium is leached more under more acidic condition (Khanna and Ulrich 1991; Langusch et al. 2003) the higher acidity of water might have promoted the leaching of potassium from beech branches. The calculated amount of leached potassium in the throughfall was highest under the mixed canopies in both plots (Fig. 3).

The calculations based on Ulrich's model (1983), showed that the canopy leaching was an important source of base cations in the throughfall. In all canopy classes and in both plots more than $50 \%$ of $\mathrm{Ca}^{2+}$, about $60 \%$ of $\mathrm{Mg}^{2+}$ and about $90 \%$ of $\mathrm{K}^{+}$in the throughfall originated from canopy leaching. These findings were in good agreement with the values reported by Nordén (1994a) for the throughfall under beech crowns in three mixed deciduous forests in Southern Sweden. His data has showed that, depending on the site conditions, the canopy leaching was the source of $60-70 \%$ of $\mathrm{Ca}, 50-80 \%$ of $\mathrm{Mg}$ and $80-90 \%$ of $\mathrm{K}$ in beech throughfall. Based on 15 case studies in beech and spruce forests in Europe, Rothe et al. (2002a) have reported slightly lower values: $37 \%$ for $\mathrm{Ca}, 34 \%$ for $\mathrm{Mg}$ and $80 \%$ for $\mathrm{K}$.

In addition to throughfall, stemflow can also be of importance for the localised input of base cations to the forest floor, particularly under the beech canopies (Nihlgård 1970; Levia and Frost 2003; Staelens et al. 2007). The calculation of stemflow input of $\mathrm{K}, \mathrm{Ca}$ and $\mathrm{Mg}$ in the beech canopy class in our study during the leafed period showed that the input of $\mathrm{K}$ per quadrate meter was increased compared to the input via throughfall to $8 \%$ in the SDP and to $15 \%$ in the BDP, while for $\mathrm{Ca}$ and $\mathrm{Mg}$ the relative contribution of stemflow was negligible. For the leafless period the values might be slightly higher, but calculation on the annual basis is difficult due to high seasonal and site dependant variability of both water fluxes and element concentrations in stemflow and throughfall, found in literature (Nihlgård 1970; Benecke 1984; Levia and Frost 2003; Staelens et al. 2007).

\section{Litterfall}

Rothe and Binkley (2001) have suggested that the higher mobility of beech leaves together with lower mobility of the spruce litter will cause higher total foliar litterfall amounts under spruce canopies, but we did not find such a pattern. In our study, the distribution pattern of total foliar litterfall was fairly homogeneous and did not cause any variation in nutrient input among different canopy categories. This might be related to the fact that we had such an extreme case of mixtures in terms of beech-spruce proportions.

The fluxes of needle litter, with exception of the gaps, followed the same order in both plots, SDP and BDP (spruce $>$ mixed $>$ beech). In accordance with Rothe (1997), this order may depend on the horizontal distribution of needle litterfall. However, the flux of needle litter in a gap may strongly be influenced by the location, size and shape of the gap as well as the wind direction and the height of the surrounding trees. As shown in Fig. 1b, the gap in SDP was surrounded by the canopy of old growth spruce trees on three sides. Hence, the needle fall from the periphery of surrounding spruce canopies may increase the flux of needle litter in the SDP gap.

The distribution of beech litter that has accounted for more than $90 \%$ of total foliar litter in all canopy categories in the BDP was very homogeneous. In the SDP the mobility of beech leaves, which, depending on canopy category, contributed $17-43 \%$ to the total foliar litterfall, was more restricted, possibly due to the effect of 
surrounding spruce trees. Such a distribution together with small differences in the concentration of most of the elements in beech and spruce foliar litterfall have resulted in similar element fluxes via foliar litterfall among different canopy categories in both plots, with the exception of $\mathrm{Mg}$. In the case of $\mathrm{Mg}$ the element concentration in leaf litter was considerably higher than in needle litter (Fig. 4). This has caused significantly lower $\mathrm{Mg}$ input under spruce canopies compared with other canopy categories in the SDP. In the BDP, the same tendency could be observed, but the differences were not significant due to more homogeneous distribution of beech leaf litter. The difference in Mg input via litterfall under the spruce canopy was reflected in lower $\mathrm{Mg}$ concentration in the soil organic layer under the spruce canopy compared to other canopy classes at the studied plots (Hojjati and Lamersdorf 2008). This is in accordance with results reported by Thelin et al. (2002), who have found higher Mg concentration, in the upper $(0-10 \mathrm{~cm})$ mineral soil under spruce trees growing with beech in mixtures than under spruce in monoculture stands.

Nutrient concentrations in beech and in spruce foliar litterfall in our study were within the range reported by other authors for foliar litterfall of these species (Matzner 1988; Pedersen and Bille-Hansen 1999; Berg and Gerstberger 2004), with exception of Mn, which was a slightly higher in our plots, particularly in the BDP. The element fluxes via litterfall in all canopy classes in the BDP were always higher than in the corresponding canopy categories in the SDP, mainly due to the higher total amount of foliar litter in this plot (Table 5), but also due to a higher nutrient concentration in both needle and leaf litterfall for the case of K, Ca and Mn (Fig. 4).

Although the concentration of elements found in foliar litter will also depend on processes of nutrient resorption and leaching, the higher concentrations of $\mathrm{K}$ and $\mathrm{Ca}$ in foliar litterfall in the BDP indicate a positive effect of beech trees on the nutrient availability of these elements in mixed beech-spruce stands. In the case of $\mathrm{Ca}$, the ability of beech trees to improve the Ca circulation in spruce stands due to $\mathrm{Ca}$ uptake from deeper soil horizons (known as the Ca-pump effect) has previously been suggested (e.g. Berger et al. 2006). With regard to $\mathrm{K}$, our results correspond to those of Thelin et al. (2002) who have reported substantially higher $\mathrm{K}$ concentrations in current year needles of Norway spruce growing in mixtures with beech compared with spruce monocultures. Ca concentrations in needles in their study varied from 1.4 to $6.0 \mathrm{mg} / \mathrm{g}$ and showed no significant differences between beech-spruce mixtures and spruce monocultures, but the median concentration was $34 \%$ higher in mixed stands than in pure spruce stands. In contrast, Rothe et al. (2003) who have used a different approach (known as the neighbourhood approach) to investigate the effects of broadleaves on nutrient status of coniferous in various mixed stands have not observed any positive effects.

\section{Total nutrient inputs}

The importance of throughfall and litterfall fluxes in total nutrient inputs to the soil surface varies depending on the nature of the elements. Stachurski and Zimka (2002) showed that nearly $80 \%$ of potassium in foliage existed in ionic form, while for $\mathrm{Mg}$ and $\mathrm{Ca}$ the values were only 40 and $20 \%$, respectively. As $\mathrm{K}$ is highly leachable, throughfall is the main flux for $K$ to the soil surface in forest ecosystems (e.g. Nordén 1994b; Duchesne et al. 2001; Langusch et al. 2003). High rates of $K$ inputs via throughfall were also observed in our study and differences between canopy categories can clearly be attributed to differences in $\mathrm{K}$ throughfall inputs. High total $\mathrm{K}$ inputs under mixed canopies may therefore be caused by higher $\mathrm{K}$ leaching in this canopy category.

In contrast to $\mathrm{K}$, litterfall was the major source of inputs for Ca in all canopy classes. However, in the spruce canopy categories in both plots and in mixed canopy category in the SDP the relative contribution of throughfall to the total $\mathrm{Ca}$ fluxes was close to $50 \%$. The $\mathrm{Ca}$ inputs via litterfall were very similar among all canopy categories (Table 5). The total inputs of $\mathrm{Ca}$ was higher under spruce and mixed canopy categories, reflecting the differences in $\mathrm{Ca}$ inputs via throughfall among the canopy categories (Table 3). Lower $\mathrm{Mg}$ inputs with litterfall were analysed for the spruce canopy categories compared with the beech and the mixed canopy classes (especially pronounced in the SDP). The lower Mg litterfall fluxes under spruce might be balanced by higher $\mathrm{Mg}$ fluxes via throughfall. However, $\mathrm{Mg}$ input via throughfall may differ from litterfall input with respect to plant availability or soil leaching processes. Even though litterfall may have a homogenising effect on nutrient inputs to the soil surface, as was observed in our study, the total nutrient fluxes under different canopy categories in a mixed beech spruce forest will differ due to spatial patterns of throughfall.

\section{Conclusions}

Canopy composition in a mixed spruce and beech stand has a great impact on the heterogeneity in element and water fluxes via throughfall. The differences in throughfall water flux and chemistry under the canopies of beech and spruce in the two contrasting cases of admixtures were in agreement with previously reported differences between these species grown in monocultures. The results suggest that crowns of individual trees may show the same behaviour 
for throughfall nutrient inputs in different kinds of sprucebeech mixed stands. However, further investigations in other types of mixed stands are needed to verify clearly such a linear response.

The chemistry of throughfall water in the gap and under mixed canopy categories will obviously reflect the differences between beech and spruce canopies, but will not necessarily represent a simple average of the throughfall characteristics of the two species, as was clearly demonstrated for the case of $\mathrm{K}$ in our study. The significantly higher $\mathrm{K}$ fluxes under the mixed canopies might have resulted from an enhancing effect of spruce throughfall on $\mathrm{K}^{+}$leaching from beech. Further investigations with sample collection at different heights are needed to monitor the gradual changes in throughfall chemistry within the mixed canopies and to clarify the interaction mechanisms between beech and spruce. The impact of an individual spruce tree in a beechdominated site induced higher degrees of spatial heterogeneity with respect to nutrient inputs via throughfall compared to individual beech trees in a spruce-dominated site.

The foliar litterfall was a source of homogeneity in nutrient inputs in our study. Our results indicate that on nutrient-poor sites like Solling the increased proportion of beech in a mixed beech-spruce stand can probably enhance the base cation (especially $\mathrm{Ca}$ ) cycle through the pumping effect of beech trees and the interception capacity of spruce foliage.

Acknowledgments We would like to express our special gratitude to the Iranian Ministry of Sciences, Research and Technology (MSRT), to the Swedish research council FORMAS and to Carls Tryggers foundation for Scientific research (Sweden) for financial support for two of the authors of the article. We would like to thank the Institute of Soil Science of Temperate and Boreal Ecosystems at the Georg-August University of Goettingen for its great hospitality, expertise and all the technical and financial support provided in field equipment installations, data collection and chemical analyses. We are particularly grateful to D. Böttger and N. Frischbier for their expert technical assistance and to all the laboratory assistants at the Institute of Soil Science of Temperate and Boreal Ecosystems for analysing our samples. We are very grateful to two anonymous referees for valuable comments on an earlier version of the manuscript.

Open Access This article is distributed under the terms of the Creative Commons Attribution Noncommercial License which permits any noncommercial use, distribution, and reproduction in any medium, provided the original author(s) and source are credited.

\section{References:}

Augusto L, Ranger J (2001) Impact of tree species on soil solutions in acidic conditions. Ann For Sci 58:47-58. doi:10.1051/forest: 2001102

Augusto L, Ranger J, Binkley D, Rothe A (2002) Impact of several common tree species of European temperate forests on soil fertility. Ann For Sci 59:233-253. doi:10.1051/forest:2002020
Beier C, Hansen K, Gundersen P (1993) Spatial variability of throughfall fluxes in a spruce forest. Environ Pollut 81:257-267. doi:10.1016/0269-7491(93)90208-6

Benecke P (1984) Der Wasserumsatz eines Buchen- und eines Fichtenwaldökosystems im Hochsolling. J.D. Sauerländer's Verlag, Frankfurt am Main, pp 1-159

Berg B, Gerstberger P (2004) Element fluxes with litterfall in mature stands of norway spruce and European beech in Bavaria, South Germany. In: Matzner E (ed) Biogeochemistry of forested catchments in a changing environment, ecological studies, vol 172. Springer, Berlin, pp 271-278

Berger TW, Swoboda S, Prohaska T, Glatzel G (2006) The role of calcium uptake from deep soils for spruce (Picea abies) and beech (Fagus sylvatica). Forest Ecol Manage 229:234-246

Bolte A, Villanueva I (2006) Interspecific competition impacts on the morphology and distribution of fine roots in European beech (Fagus sylvatica L.) and Norway spruce (Picea abies (L.) Karst.). Eur J For Res 125:15-26. doi:10.1007/s10342-005-0075-5

Borken W, Xu YJ, Davidson EA, Beese F (2002) Site and temporal variation of soil respiration in European beech, Norway spruce, and Scots pine forests. Glob Change Biol 8:1205-1216. doi: 10.1046/j.1365-2486.2002.00547.x

Bredemeier M (1988) Forest canopy transformation of atmospheric deposition. Water Air Soil Pollut 40:121-138

Duchesne L, Ouimet R, Camire C, Houle D (2001) Seasonal nutrient transfers by foliar resorption, leaching, and litterfall in a northern hardwood forest at lake Clair Watershed, Quebec, Canada. Can J For Res 33(2):333-344. doi:10.1139/cjfr-31-2-333

Hagen-Thorn A, Varnagiryte B, Nihlgard B, Armolaitis K (2006) Autumn nutrient resorption and losses in four deciduous forest tree species. For Ecol Manage 228(1-3):33-39. doi: 10.1016/j.foreco.2006.02.021

Hansen K (1995) In-Canopy throughfall measurements in Norway spruce: water flow and consequences for ion fluxes. Water Air Soil Pollut 85:2259-2264. doi:10.1007/BF01186170

Heinrichs H (1989) Aufschlussverfahren in der analytischen. Geochemie (Teil 1). Labor Prax 12(89):1140-1146

Hojjati SM, Lamersdorf NP (2008) The impact of canopy composition on forest floor and soil properties in a mixed spruce-beech stand in central. Europe (in preparation)

Hojjati SM (2008) The impact of canopy composition on the nutritional status of an admixed spruce and beech forest at Solling, central Germany. Dessertation-Buesgen Institute-Soil Science of Temperate and Boreal Ecosystems, Georg-August Göttingen University

Hooper DU, Chapin FS, Ewel JJ, Hector A, Inchausti P, Lavorel S, Lawton JH, Lodge DM, Loreau M, Naeem S, Schmid B, Setälä H, Symstad AJ et al (2005) Effects of biodiversity on ecosystem functioning: a consensus of current knowledge. Ecol Monogr 75:3-35

Khanna PK, Ulrich B (1991) Ecochemistry of temperate deciduous forests. In: Röhrig E, Ulrich B (eds) Ecosystems of the World, Chap. 7. Elsevier, Amsterdam

Langusch J, Borken W, Armbruster M, Diese N, Matzner E (2003) Canopy leaching of cations in central European forest ecosystems - a regional assessment. J Plant Nutr Soil Sci 166:168-174. doi:10.1002/jpln.200390024

Larsen B (1995) Ecological stability of forests and sustainable silviculture. For Ecol Manage 73:85-96. doi:10.1016/03781127(94)03501-M

Lebert M, Nys C, Forgeard F (2001) Litter production in an Atlantic beech (Fagus sylvatica L) time sequence. Ann For Sci 58:755768. doi:10.1051/forest:2001161

Levia DF Jr, Frost EE (2003) Variability of throughfall volume and solute inputs in wooded ecosystems. Prog Phys Geogr 30(5): 605-632. doi:10.1177/0309133306071145 
Lovett GM (1994) Atmospheric deposition of nutrients and pollutants in North America: an ecological perspective. Ecol Appl 4:629650. doi: $10.2307 / 1941997$

Lovett GM, Nolan SS, Driscoll CT, Fahey TJ (1996) Factors regulating throughfall flux in a New Hampshire forested landscape. Can J For Res 26:2134-2144. doi:10.1139/x26-242

Matzner E (1988) Der Stoffumsatz zweier Waldökosysteme im Solling. Berichte des Forschungszentrums Waldökosysteme/ Waldsterben A40:1-217

Meesenburg H, Meiwes KJ, Rademacher P (1995) Long term trends in atmospheric deposition and seepage output in northwest German forest ecosystems. Water Air Soil Pollut 85:611-616. doi:10.1007/BF00476896

Nihlgård B (1970) Precipitation, its chemical composition and effect on soil water in a beech and a spruce forest in south Sweden. Oikos 21:208-217. doi:10.2307/3543676

Nordén U (1994a) Acid deposition and throughfall fluxes of elements as related to tree species in deciduous forests of South Sweden. Water Air Soil Pollut 60:209-230. doi:10.1007/BF00282624

Nordén U (1994b) Leaf litterfall concentrations and fluxes of elements by deciduous tree species. Scand J For Res 9(1):9-16

Müller-Using, Rademacher (2004) Bioelemententzug bei der Holznutzung in Rein- und Mischbeständen aus Buche und Fichte. Ber Forschungszentrum Waldokosysteme Gottingen 71:81-110

Oberdorfer E (1992) Süddeutsche Pflanzengesellschaften. Teil IV: Wälder und Gebüsche, 2nd edn. G. Fischer, Jena

Olsthoorn AFM, Bartelink HH, Gardiner JJ, Pretzsch H, Hekhuis HJ, Franc A (eds) (1999) Management of mixed-species forest: silviculture and economics. IBN Scient Contrib 15: 1-389

Oulehle F, Hruška J (2005) Tree species (Picea abies and Fagus sylvatica) effects on soil water acidification and aluminium chemistry at sites subjected to long-term acidification in the Ore Mts., Czech Republic. J Inorg Biochem 99:1822-1829. doi: 10.1016/j.jinorgbio.2005.06.008

Pedersen LB, Bille-Hansen J (1999) A comparison of litterfall and element fluxes in even aged Norway spruce, sitka spruce and beech stands in Denmark. For Ecol Manage 114:55-70. doi: 10.1016/S0378-1127(98)00381-8

Raat KJ, Draaijers GPJ, Scaap MG, Tietema A, Verstraten JM (2002) Spatial variability of throughfall water and chemistry and forest floore water content in a Douglas fir forest stand. Hydrol Earth Syst Sci 6(3):363-374

Rothe A (1997) Einfluß des Baumarten-anteils auf Durchwurzelung, Wasserhaushalt, Stoffhaushalt und Zuwachsleistung eines FichtenBuchen-Misch-bestandes am Standort Höglwald.Schriftenreihe der Forstwissenshaftlichen Fakultät der Universität München und der Bayerischen Landesanstalt für Wald und Forstwirtschaft. Dissertation

Rothe A, Binkley D (2001) Nutritional interactions in mixed species forests: a synthesis. Can J For Res 31:1855-1870. doi:10.1139/ cjfr-31-11-1855

Rothe A, Huber C, Kreutzer K, Weis W (2002a) Deposition and soil leaching in stands of Norway spruce and European beech: results from the Höglwald research in comparison with other European case studies. Plant Soil 240:33-45. doi:10.1023/A: 1015846906956

Rothe A, Kreutzer K, Küchenhoff H (2002b) Influence of tree species composition on soil and soil solution properties in two mixed spruce-beech stands with contrasting history in Southern Germany. Plant Soil 240:47-56. doi:10.1023/A:1015822620431

Rothe A, Ewald J, Hibbs DE (2003) Do admixed broadleaves improve foliar nutrient status of conifer tree crops? For Ecol Manage 172:327-338. doi:10.1016/S0378-1127(01)00800-3
Růžička Š (1994) Throughfall quality and quantity in polluted and damaged ecosystems in Northern Bohemia. Water Air Soil Pollut 83:205-218

Seiler J, Matzner E (1995) Spatial variability of throughfall chemistry and selected soil properties as influenced by stem distance in a mature Norway spruce (Picea abies, Karst.) stand. Plant Soil 176:139-147. doi:10.1007/BF00017684

Stachurski A, Zimka JR (2002) Atmospheric deposition and ionic interactions within a beech canopy in the Karkonosze Mountains. Environ Pollut 118:75-87. doi:10.1016/S0269-7491(01) 00238-X

Staelens J, De Schrijver A, Verheyen K, Verhoest NEC (2006) Spatial variability and temporal stability of throughfall water under a dominant beech (Fagus sylvatica L.) tree in relationship to canopy structure. Environ Pollut 142:254-263. doi:10.1016/j. envpol.2005.10.002

Staelens J, De Schrijver A, Verheyen K (2007) Seasonal variation in throughfall and stemflow chemistry beneath a European beech (Fagus sylvatica) tree in relation to canopy phenology. Can J For Res 37:1359-1372. doi:10.1139/X07-003

Stefan K, Fürst A, Hacker R, Bartels U (1997) Forest Foliar Condition in Europe-results of large-scale foliar chemistry surveys (survey 1995 and data from previous years), EC-UN/EC, Austrian Federal Research Centre, p 207

Sverdrup H, Stjernquist I (2002) Developing principles and models for sustainable forestry in Sweden. Kluwer, Dordrecht

Thelin G, Rosengren U, Callesen I, Ingerslev M (2002) The nutrient status of Norway spruce in pure and in mixed-species stands. For Ecol Manage 160:115-125. doi:10.1016/S0378-1127(01) 00464-9

Ulrich B (1983) Interaction of forest canopies with atmospheric constituents: $\mathrm{SO}_{2}$, alkali and earth alkali cations and cloride. In: Ulrich B, Pankrath J (eds) Effects of accumulation of air pollutants in forest ecosystems. D. Reidel, Dordrecht (Holland), pp 33-45

Ulrich B (1994) Nutrient and acid-base budget of central European forest ecosystem. In: Godbold D, Hüttermann A (eds) Effects of acid rain on forest processes, Chap. 1. Wiley-Liss publication, New York

Weckesser M (2003) Die Bodenvegetation von Buchen-FichtenMischbeständen im Solling-Struktur. Diversität und Stoffhaushalt, Cuvillier, Göttingen

Whelan MJ, Anderson JM (1996) Modelling spatial patterns of throughfall and interception loss in a Norway spruce (Picea abies) plantation at the plot scale. J Hydrol (Amst) 186:335-354. doi:10.1016/S0022-1694(96)03020-X

Whelan MJ, Sanger LJ, Baker M, Anderson JM (1998) Spatial patterns of throughfall and mineral ion deposition in a lowland Norway spruce (Picea abies) plantation at the plot scale. Atmos Environ 32:3493-3501. doi:10.1016/S1352-2310(98)00054-5

Wilpert KV, Mies E (1995) The influence of stand structure and tree species on mineral cycling. In: Nutrient uptake and cycling in forest ecosystems. European Commission, Brussels. Off. Publ. 8

Wilpert KV, Zirlewagen D, Kohler M (2000) To what extent can silvicultural enhance sustainability of forest sites under the immission regime in central Europe? Water Air Soil Pollut 122:105-120. doi:10.1023/A:1005275219108

Zinke PJ (1962) The pattern of individual forest trees on soil properties. Ecology 43:130-133. doi:10.2307/1932049

Zirlewagen D, von Wilpert K (2001) Modelling water and ion fluxes in a highly structured, mixed-species stand. For Ecol Manage 143:27-37. doi:10.1016/S0378-1127(00)00522-3 